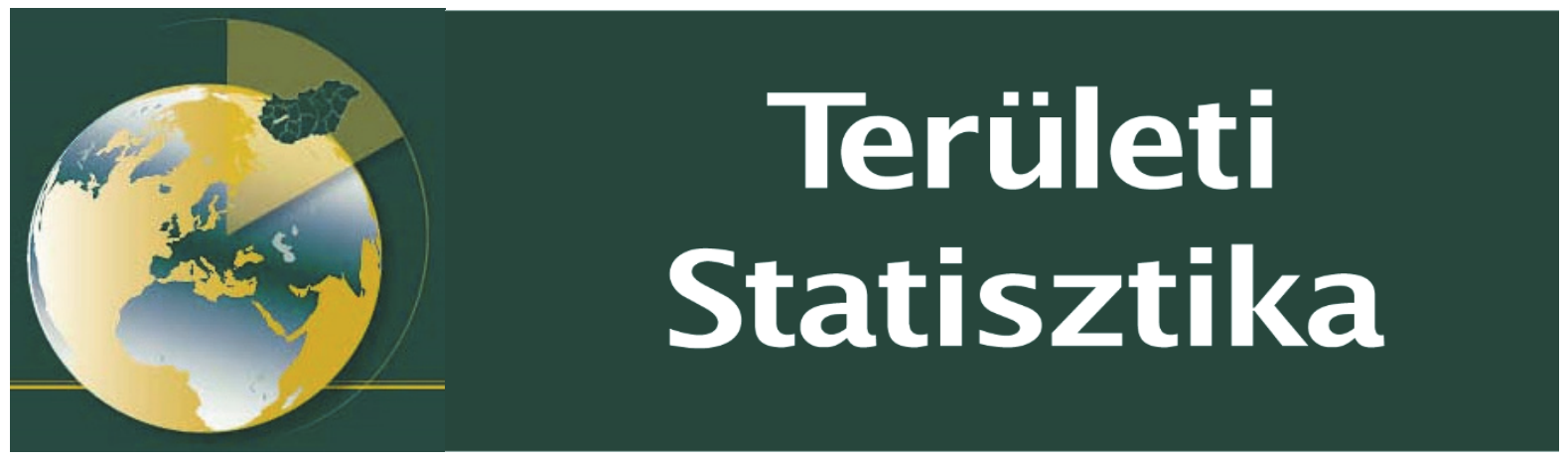

Közzététel: 2019. április 16.

A tanulmány címe: Szerzők:

Két régió - két eltérő út: a német feldolgozóipari kis- és középvállalatok fejlődése

Páger Balázs MTA KRTK RKI, E-mail: pagerb@rkk.hu

Kovács Szilárd Eötvös József Főiskola, Gazdálkodási Intézet, E-mail: kovacs.szilard@ejf.hu

Nick Gábor MTA SZTAKI, E-mail: nick.gabor@sztaki.mta.hu

https://doi.org/10.15196/TS590201

Az alábbi feltételek érvényesek minden, a Központi Statisztikai Hivatal (a továbbiakban: KSH) Területi Statisztika c. folyóiratában (a továbbiakban: Folyóirat) megjelenó tanulmányra. Felhasználó a tanulmány, vagy annak részei felhasználásával egyidejüleg tudomásul veszi a jelen dokumentumban foglalt felhasználási feltételeket, és azokat magára nézve kötelezốnek fogadja el. Tudomásul veszi, hogy a jelen feltételek megszegéséböl eredố valamennyi kárért felelösséggel tartozik.

1) A jogszabályi tartalom kivételével a tanulmányok a szerzői jogról szóló 1999. évi LXXVI. törvény (Szjt.) szerint szerzői műnek minősülnek. A szerzői jog jogosultja a KSH.

2) A KSH földrajzi és időbeli korlátozás nélküli, nem kizárólagos, nem átadható, téritésmentes felhasználási jogot biztosít a Felhasználó részére a tanulmány vonatkozásában.

3) A felhasználási jog keretében a Felhasználó jogosult a tanulmány:

a) oktatási és kutatási célú felhasználására (nyilvánosságra hozatalára és továbbítására a

4. pontban foglalt kivétellel) a Folyóirat és a szerző(k) feltüntetésével;

b) tartalmáról összefoglaló készítésére az írott és az elektronikus médiában a Folyóirat

és a szerző(k) feltüntetésével;

c) részletének idézésére - az átvevő mú jellege és célja által indokolt terjedelemben és az eredetihez híven - a forrás, valamint az ott megjelölt szerző(k) megnevezésével.

4) A Felhasználó nem jogosult a tanulmány továbbértékesítésére, haszonszerzési célú felhasználására. Ez a korlátozás nem érinti a tanulmány felhasználásával elóállított, de az Szjt. szerint önálló szerzői műnek minősülő mú ilyen célú felhasználását.

5) A tanulmány átdolgozása, újra publikálása tilos.

6) A 3. a)-c.) pontban foglaltak alapján a Folyóiratot és a szerző(ke)t az alábbiak szerint kell feltüntetni:

„Forrás: Területi Statisztika c. folyóirat 59. évfolyam 2. számában megjelent, Páger Balázs - Kovács Szilárd - Nick Gábor által irt Két régió - két eltéro" út: a német feldolgozóipari kis-és középvállalatok fejlódése c. tanulmány"

7) A Folyóiratban megjelenő tanulmányok kutatói véleményeket tükröznek, amelyek nem esnek szükségképpen egybe a KSH, vagy a szerzők által képviselt intézmények hivatalos álláspontjával. 


\section{Két régió - két eltérő út: a német feldolgozóipari kis- és középvállalatok fejlödése}

\section{Development of German manufacturing SMEs: two regions - two different ways}

Páger Balázs

MTA KRTK RKI

E-mail: pagerb@rkk.hu

Kovács Szilárd

Eötvös József Főiskola,

Gazdálkodási Intézet

E-mail: kovacs.szilard@ejf.hu

Nick Gábor

MTA SZTAKI

E-mail:

nick.gabor@sztaki.mta.hu

Kulcsszavak:

Németország,

kis- és középvállalatok,

feldolgozóipar,

Bajorország,

Szászország,

Ipar 4.0
A tanulmány célja, hogy bemutassa azokat a párhuzamokat és eltéréseket, amelyek a kis- és középvállalatok regionális különbségeit jellemzik Németországban. A szerzők a kelet- és a nyugatnémet területek közötti törésvonalak ismertetésével két tartomány, Bajorország (Bayern) és Szászország (Sachsen) kis- és középvállalati struktúráját mutatják be. Bajorország tipikus példája a családi kis- és középvállalatokra (Mittelstand) ${ }^{1}$ alapozott fejlődési pályának. Ezeknek a vállalatoknak meghatározó szerepük van a bajor helyi és regionális gazdaságban. Szászország a keletnémet térség egyik jelentôs ipari és vállalkozói múlttal rendelkező tartománya, amely kismértékben szenvedte el az újraegyesítéssel járó problémákat. A tartomány feldolgozóipari ágazataiban a kis- és középvállalatok vannak többségben. A nagyvállalatok kevésbé meghatározó szerepe a rendszerváltást követő radikális átalakulással magyarázható, melynek során sok állami nagyvállalatot számoltak fel. A tanulmány utolsó fejezete a német feldolgozóipar kis- és középvállalatai szempontjából kiemelt fontosságú Ipar 4.0 projektek szerepét és területi eloszlását elemzi.

\footnotetext{
${ }^{1}$ A tanulmányban a kis- és középvállalat és Mittelstand vállalat egymás szinonimái.
} 
One The aim of the study is to highlight the similarities and differences in the development paths of manufacturing small- and medium-sized enterprises (SMEs) in Eastern and Western Germany. After outlining the dividing lines between Eastern and Western German territories by various dimensions, the authors review the SME structure in two German federal states, Bavaria and Saxony. In the Bavarian manufacturing sector, a family-SMEs-based development path is typical. These SMEs play an important role in the Bavarian local and regional economy. Saxony, being among those federal states in Eastern Germany which have a significant industrial past and strong entrepreneurial traditions, suffered relatively small losses from the shock of the German reunification. The Saxon

Keywords: manufacturing industries are also dominated by

SMEs. The less dominant role of large firms can small- and medium-sized be explained by the radical transformation after

firms, political transition, when former large, statemanufacturing, section of the study investigates the territorial

Bavaria, differences between Industry 4.0 projects as they

Saxony, have significant impact on the future of German Industry 4.0 manufacturing SMEs.

Beküldve: 2019. január 7.

Elfogadva: 2019. február 17.

\section{Bevezetés}

A német gazdasági csoda egyik alapeleme a Mittelstand vállalatok rétege. Ezeknek a vállalatoknak közös jellemzőjük, hogy nemzetközi megjelenésükben elsősorban (méretükből adódóan) a réspiacokra koncentrálnak. Így ezek a vállalatok jelentős innovációs potenciállal rendelkeznek (Holz 2013). A globális piacvezetô német vállalatok többsége Mittelstand vállalatként indult, és az európai trendekkel ellentétben nem a tercier szektorban, hanem a feldolgozóiparban jelentek meg (Welter et al. 2015).

Németország nyugati országrésze a második világháborút követő újjáépítés legsikeresebb modelljét mutatta. A sikeresen végrehajtott gazdasági átalakulásnak köszönhetően az 1970-es évekre Nyugat-Németország lett a világ második legjelentő-

Területi Statisztika, 2019, 59(2): 129-151; DOI: 10.15196/TS590201 
sebb ipari hatalma. Az északi területeket a hagyományos, döntően nyersanyag- és energiaigényes nehézipari ágazatok (vas- és acélgyártás, hajóipar) jellemezték. Ezekben az ágazatokban a termelési feltételeknek, a világgazdasági folyamatoknak és az exportorientált gazdaságpolitikának köszönhetően jelentős világpiaci részesedést ért el az akkori Német Szövetségi Köztársaság (NSZK) (Vonyó 2006). A déli tartományokban (Bajorország, Baden-Württemberg) egy szerkezetében, termelési struktúrájában eltérő ipar bontakozott ki. Ágazati szempontból az elektronika, a repülógépgyártás, a finommechanika, a hírközlés és a speciális gépgyártás jellemezte e területet a háborút követően, ami megalapozta a - napjainkban is jelentős - feldolgozóipart. Az északi tartományoktól eltérôen a (német viszonylatban megkésett) bajor iparosodás kulcsszereplói nem a nagyvállalatok voltak, hanem a kis- és középvállalkozások, melyek közül több Kelet-Németországból települt át a háborút követő években (Erker 1991). A második világháború utolsó éveiben, valamint az azt követő időszakban számos gazdasági szereplő (egyes becslések szerint az összes keletnémet vállalkozás 9-13\%-a) hagyta el a keletnémet területet, és települt át a nyugatnémet tartományokba (Buenstorf-Guenther 2011, Falck et al. 2013). Az áttelepülés mellett jelentôs mértékű népesség- (humán tôke) vándorlás is jellemezte ezt az időszakot (Falck et al. 2013, Fritsch-Wyrwich 2014). A két országrész között fennálló különbségek nyilvánvaló okokra vezethetők vissza: a keletnémet tartományok területén a második világháború után létrehozott, mintegy négy évtizedig fennálló Német Demokratikus Köztársaság (NDK) gazdaságpolitikája különbözött a nyugati országrészétől. Horváth (2013) az olasz Mezzogiorno és Észak-Olaszország éles elkülönülésének példájához hasonlította a két német országrész között az újraegyesítés idején meglévô társadalmi-gazdasági különbségeket. Ezek forrása nem a munkaerő szakképzettségében, hanem a gyenge infrastrukturális ellátottságban, valamint az üzleti környezetben keresendő (Horváth 2013).

A tanulmány második fejezetében a kelet- és nyugatnémet kis- és középvállalatok jellemzőit hasonlítjuk egymáshoz, melynek célja a két térség között meghúzódó törésvonalak ismertetése. A harmadik és negyedik fejezetben Bajorország és Szászország vállalati struktúráját tekintjük át, részletezzük a feldolgozóipari kis- és középvállalatokat. Bajorországban a második világháborút követó évtizedekben a Mittelstand vállalatoknak jelentôs szerepük volt a tartományban végbement gazdasági fejlődésben. Szászország pedig az egyik jelentős ipari és vállalkozói múlttal rendelkező keletnémet tartomány. A tervgazdasági időszakot követő gazdasági visszaesés ebben a tartományban volt a legkisebb mértékú, így itt indulhatott meg leggyorsabban a kis- és középvállalati szektor újjáépülése. Végül a tanulmányban ismertetjük, hogy a jövő egyik nagy ígéretének tartott Ipar 4.0 megoldások milyen szerepet játszhatnak a kis- és középvállalati szektorban, és a projektek területi eloszlása milyen mintákat tükröz. Az Ipar 4.0 a kis- és középvállalatok innovációs közege fontos és kiemelten vizsgálandó kérdés, mivel az innováció befolyásolja a regionális fejlődést, és egy régió sikere az innovációs rendszerek beágyazottságától is függ (Rechnitzer-

Területi Statisztika, 2019, 59(2): 129-151; DOI: 10.15196/TS590201 
Smahó 2011). A versenyképes régiók alkalmasak az innovatív megoldások bevezetésére. Ebben kiemelt szerepet kapnak a térbeli elhelyezkedést koncentráló tartományok, városok. A felsorolt gazdasági szereplők együtt alkotják a területi tőke jelentős részét, valamint befolyásolják a helyi innovációs környezetet. Így, az előzőek alapján ismertetjük a gazdaság szerkezetének, a területi ismérveknek és az Ipar 4.0 innovációinak, megvalósult projektjeinek összefüggéseit. Tanulmányunk kizárólag Németország vizsgálatára terjed ki, más, ipari fejlettség szempontjából a világpiacon domináns országot - Egyesült Államok, Kína, Japán - nem elemzünk, és nem vetjük egybe ezen országok helyzetét Németországéval.

\section{Fejlödési trendek a keleti és a nyugati tartományokban}

Az 500 legjelentősebb német vállalatról készített (Die Welt TOP 500) 2013-as rangsor alapján 466 vállalatnak a korábbi nyugatnémet területen található a székhelye, míg 34-nek a keletnémet területen (Ragnitz et al. 2015). Hasonlóan jelentős eltéréseket mutat a két országrész között a Die Deutsche Wirtschaft 10 ezer legjelentősebb Mittelstand vállalatot tartalmazó listája ${ }^{2}$. Az egy millió lakosra jutó TOP $10000^{3}$ rangsorban szereplő vállalatok száma magasabb a nyugati tartományokban (átlag 136,7) a keletiekhez képest (átlag Berlinnel 63,7; Berlin nélkül 61,2). Kiemelkedőek a nyugati tartományokon belül a két városállam (Hamburg 202, Bréma 180 vállalat), valamint Baden-Württemberg (170) és Bajorország (155) értékei. Ezzel szemben a legjobban teljesítő keleti tartomány, Szászország (81) a 11. helyen állt, azaz mind a 10 nyugati tartomány előtte helyezkedett el a rangsorban.

A keleti tartományoknál Szászországtól kissé lemaradva következik Türingia (74) a rangsorban, majd (a 14. helyen) Szász-Anhalt (59). A legalacsonyabb teljesítményú tartományok Brandenburg (47) és Mecklenburg-Elő-Pomeránia (45). Szintén ennek a felmérésnek része, hogy városi szinten is megfigyelték a telephelyek szóródását, és rangsorolták a 100 legtöbb, TOP 10 000-es céggel rendelkező német várost ${ }^{4}$ A rangsorban a keletnémet városok közül a 23. helyen Drezda szerepelt, 36 vállalattal, majd Lipcse (32. hely, 31 vállalat), Chemnitz (48. hely, 23 vállalat), Rostock (82. hely, 15 vállalat), Magdeburg (83. hely, 14 vállalat) végül a 92. helyen Erfurt $(14 \text { vállalat })^{5}$ követte.

\footnotetext{
${ }^{2}$ http://die-deutsche-wirtschaft.de/ranking-der-bundeslaender-nach-top-mittelstaendlern/ (letöltés: 2018. január 12.)

3 A Die Deutsch Wirtschaft nevű elemzőcég különböző teljesítményindikátoron keresztül vizsgálja a Mittelstand vállalatokat, így például a forgalom, a foglalkoztatottak száma, a kutatás-fejlesztési ráfordítások vagy különböző együttműködések. A cégeket egy 16 indikátorból számított index alapján rangsorolják, így jön létre a 10000 legjobban teljesítő Mittelstand vállalat listája.

4 http://die-deutsche-wirtschaft.de/wo-sich-der-mittelstand-am-wohlsten-fuehlt/ (letöltés: 2018. január 12.); A TOP 10000 német Mittelstand vállalat rangsorát az előzőekben ismertetett módon alakították ki.

${ }^{5}$ Egyenlő vállalatszám esetén a vállalatok kumulált forgalma rangsorolta a városokat.
}

Területi Statisztika, 2019, 59(2): 129-151; DOI: 10.15196/TS590201 
A keletnémet tartományokban a rendszerváltást követően jelentek meg a magántulajdonú kis- és középvállalatok. Az ezen időszakban létrejött vállalatok átlagosan kisebb méretúek voltak és kevésbé sikeresek az ugyanekkor alapított nyugatnémet vállalatokhoz képest. A keletnémet tartományokban, azokban az ágazatokban volt viszonylag magas az újonnan létrejövő vállalatok száma, amelyekben a pénzügyi, a szakmai kvalifikáltsággal kapcsolatos belépési korlátok alacsonyak voltak (kiskereskedelem, vendéglátóipar) (Welter 2007, Fritsch et al. 2014). A tudásintenzív ágazatokban múködő új vállalatok inkább a nagyvárosi térségekben jelentek meg. Ezek kialakulásában szerepe volt a regionális társadalmi-gazdasági környezetnek, a helyben meglévő tudásnak (Wyrwich 2013), valamint az újonnan kialakuló vállalatközi hálózatoknak (Heimpold 2005).

A vállalkozói aktivitásban, motivációkban, valamint a vállalatok fejlődési lehetőségeiben lévő regionális különbségeket alapvetôen a kelet- és nyugatnémet országrész társadalmi-gazdasági jellemzői határozzák meg (Fritsch 2004). Ezt példázza a kutatás-fejlesztés és innováció területén megfigyelhető trend is.

A kisebb vállalatoknál a két országrész között még viszonylag kiegyenlített a kutatás-fejlesztést végző vállalatok aránya, azonban a középvállalatoknál már jelentősek az eltérések, a nyugati vállalatok javára (Arnold et al. 2015). Ezt azonban módosítja, hogy a kelet- és nyugatnémet tartományokban eltérô az innovációs környezet, illetve a vállalati szektort a kisebb vállalatok dominálják (Fritsch-Franke 2004), továbbá hatással volt ezekre a különbségekre a térségben meglévő tudás és a tudástranszfer is (Fritsch 2004). A keletnémet területeken kevés lehetôség volt a tőkefelhalmozásra a nyugatnémet országrészhez képest, valamint hiányoztak a vállalkozói képességek (Fritsch et al. 2014). Bár az újraegyesített német állam (az Európai Unió is) az utóbbi 25 évben különböző (elsősorban pénzügyi) eszközökkel csökkentette a fejlettségi különbségeket, ennek ellenére azok még számottevőek a két térség között, a makrogazdasági mutatókban és a vállalati struktúrában (Kőrösi 2014, Fritsch et al. 2015) is.

\section{A kis- és középvállalati szektor Bajorországban}

A déli nyugatnémet tartományokban (Bajorország, Baden-Württemberg) szerkezetében, termelési struktúrájában az északi nyugatnémet tartományoktól eltérô ipar bontakozott ki. Az északi tartományokban a fontosabb gazdasági szereplók a nehézipari konszernek voltak, melyeket viszonylagos rugalmatlanság és lassú alkalmazkodás jellemzett. Ezzel szemben a bajor gazdaság szereplői általában nagyfokú rugalmasságot és gyors alkalmazkodóképességet mutattak, így versenyképesek tudtak maradni. A térség technológiai fejlődésének alapja a specializáció volt. A beszállitói kis- és középvállalati szektor hálózatokba tömörült annak érdekében, hogy a térség nagyvállalatainak (BMW, Siemens, Mercedes-Benz, Bosch) innovációorientált partnerei lehessenek (Inotai 1986).

Területi Statisztika, 2019, 59(2): 129-151; DOI: 10.15196/TS590201 
Bajorország régiói és népesebb városai

NUTS 2 regions and the most populated cities of Bavaria

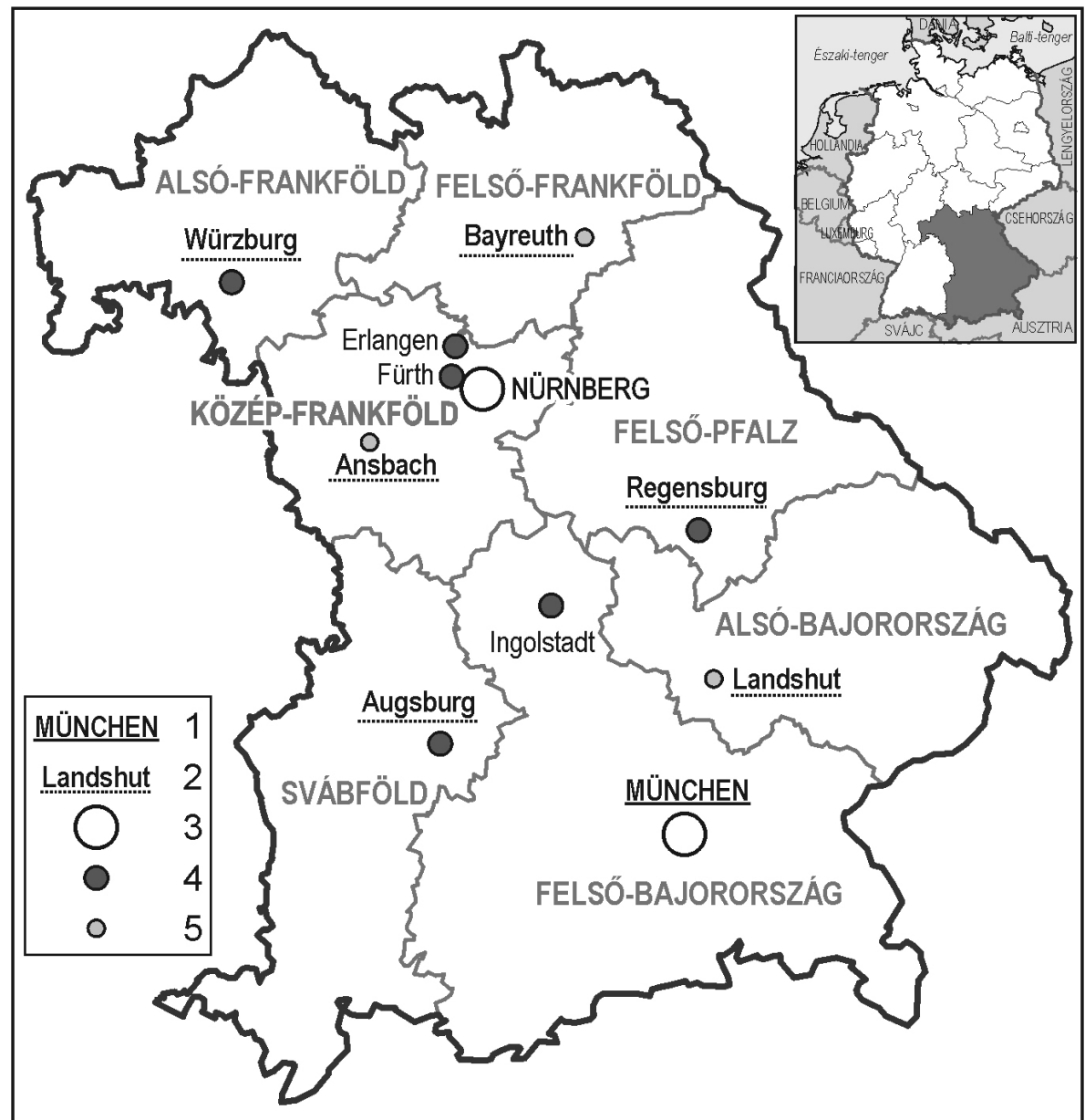

Jelmagyarázat: 1 - A tartomány székhelye; 2 - NUTS 2 térség székhelyei; 3 - 500 ezer fő feletti népességgel rendelkező város; 4 - 100 és 500 ezer fô közötti népességgel rendelkező város; 5 - 100 ezer fő alatti népességgel rendelkező város.

Bajorország (1. ábra) gazdaságának központja München és Felső-Bajorország (Oberbayern), azonban egy észak-déli gazdasági tengely is megfigyelhetô a térségben, amelynek déli súlypontja München, északi súlypontja a Nürnberg-FürthErlangen városhálózat. A vállalatok területi eloszlása alapján látható a tartományi fővárost is magában foglaló Felső-Bajorország dominanciája, hiszen a térség aránya 
több mint $40 \%$ a vállalatok számában és $50 \%$ feletti a vállalatok árbevételében (1. táblázat). Közép-Frankföld (Mittelfranken) és Svábföld (Schwaben) a két további térség, amely (Felső-Bajorország mellett) kiemelkedik a bajor régióban. Esetükben a vállalatok aránya 12-14, az árbevétel aránya pedig 10\% körüli. A két térség magasabb értékeit magyarázza, hogy Közép-Frankföld és Svábföld követi FelsőBajorországot az egy főre jutó GDP rangsorában (Kovács 2014).

1. táblázat

A vállalatok száma és árbevétele, azok megoszlása a bajorországi régióban, 2016

Distribution of the number of companies and their turnover by Bavarian region (2016)

\begin{tabular}{l|r|r|r|r}
\hline \multicolumn{1}{c|}{ NUTS 2 régió } & $\begin{array}{c}\text { Vállalatok } \\
\text { száma }\end{array}$ & $\begin{array}{r}\text { Vállalatok } \\
\text { aránya, \% }\end{array}$ & $\begin{array}{c}\text { Árbevétel, } \\
\text { milliárd euró }\end{array}$ & $\begin{array}{r}\text { Árbevétel } \\
\text { aránya, \% }\end{array}$ \\
\hline Felső-Bajorország & 257342 & 42,12 & 567,99 & 54,48 \\
Alsó-Bajorország & 56646 & 9,27 & 56,60 & 5,43 \\
Felső-Pfalz & 44322 & 7,25 & 69,41 & 6,66 \\
Felső-Frankföld & 40672 & 6,66 & 59,62 & 5,72 \\
Közép-Frankföld & 73422 & 12,02 & 101,25 & 9,71 \\
Alsó-Frankföld & 54605 & 8,94 & 78,19 & 7,50 \\
Svábföld & 83913 & 13,74 & 109,59 & 10,51 \\
Bajorország & 610922 & 100,00 & 1042,66 & 100,00 \\
\hline
\end{tabular}

Forrás: A Bajorországi Tartományi Statisztikai Hivatal adatai alapján saját szerkesztés.

Bajorország területén múködő vállalatok száma meghaladja a 610 ezret, de 93,5\%-uk az európai uniós definíció szerint mikrovállalat, azaz 2 millió euró alatti árbevétellel rendelkezik. A kisvállalatok aránya 4,5\%, míg a középvállalatoké $1 \%$. A forgalmi adatok alapján azonban a 2083 nagyvállalat az árbevétel 60\%-át adja. A maradék $40 \%$ a mikro-, a kis- és a középvállalatok között oszlik meg. Ezek alapján megállapítható, hogy a viszonylag alacsony számú középes méretú vállalkozások gazdasági ereje jelentős (2. táblázat).

Területi Statisztika, 2019, 59(2): 129-151; DOI: 10.15196/TS590201 
A bajorországi vállalatok száma és árbevétele, azok megoszlása, 2016

The number and turnover of Bavarian companies (2016)

\begin{tabular}{|c|c|c|c|c|c|}
\hline \multirow{2}{*}{$\begin{array}{l}\text { Vállalatméret- } \\
\text { kategória } \\
\text { (EU-definíció) }\end{array}$} & \multirow{2}{*}{$\begin{array}{l}\text { Árbevétel- } \\
\text { kategóriaa), } \\
\text { ezer euró }\end{array}$} & \multicolumn{2}{|c|}{ Vállalatok } & \multicolumn{2}{|c|}{ Árbevétel } \\
\hline & & $\begin{array}{l}\text { száma, } \\
\text { darab }\end{array}$ & $\begin{array}{c}\text { aránya, } \\
\%\end{array}$ & $\begin{array}{c}\text { milliárd } \\
\text { euró }\end{array}$ & $\begin{array}{c}\text { aránya, } \\
\%\end{array}$ \\
\hline \multirow{6}{*}{ Mikrovállalat } & $17,5-\quad 49$ & 165607 & 27,11 & 5,25 & 0,50 \\
\hline & $50-\quad 99$ & 119670 & 19,59 & 8,60 & 0,82 \\
\hline & $100-\quad 249$ & 136194 & 22,29 & 21,80 & 2,09 \\
\hline & $250-\quad 499$ & 72230 & 11,82 & 25,52 & 2,45 \\
\hline & $500-\quad 999$ & 48362 & 7,92 & 33,99 & 3,26 \\
\hline & $1000-1999$ & 29991 & 4,91 & 41,94 & 4,02 \\
\hline \multirow{2}{*}{ Kisvállalat } & $2000-4999$ & 21473 & 3,51 & 66,45 & 6,37 \\
\hline & $5000-9999$ & 8190 & 1,34 & 57,10 & 5,48 \\
\hline \multirow{2}{*}{ Középvállalat } & $10000-24999$ & 5211 & 0,85 & 80,38 & 7,71 \\
\hline & 25 000-49999 & 1911 & 0,31 & 66,74 & 6,40 \\
\hline Nagyvállalat & $50000-$ & 2083 & 0,34 & 634,89 & 60,89 \\
\hline \multicolumn{2}{|l|}{ Összesen } & 610922 & 100,00 & 1042,66 & 100,00 \\
\hline
\end{tabular}

a) A 17,5 ezer euró alatti bevételi kategóriába tartozó vállalatok mentesülnek a forgalmi adó fizetése alól, ezért ez az első kategória alsó határa.

Forrás: A Bajorországi Tartományi Statisztikai Hivatal adatai alapján saját szerkesztés.

A feldolgozóipar a legnagyobb ágazat a tartományban, több mint 380 milliárd eurós árbevétellel, és több mint 1,3 millió fó alkalmazottal. A feldolgozóiparban a gazdasági szervezetek 98\%-át a mikro-, kis-, és középvállalatok adják, és hozzájuk kötődik az ágazati árbevétel egyötöde. Az ágazati adatok alapján jelentősek az eltérések a feldolgozóiparon belül. A közútijármú-gyártás több mint 80 milliárd eurós forgalmat bonyolított le 2013-ban, ezzel a feldolgozóipari ágazatok közül a legjelentősebb volt. Ugyanakkor a kis- és középvállalati szektor jelentősége elmarad az átlagtól, hiszen a kisebb vállalkozásokhoz 2 milliárd eurós értékesítés köthető. A kokszgyártás és kőolaj-feldolgozásnál (17 milliárd euró), valamint az egyéb jármúgyártásnál (31 milliárd euró) a 3\%-ot sem érte el a kis- és középvállalatok aránya az értékesítésből. Ezzel szemben $50 \%$ feletti az arányuk a bútorgyártásban és az egyéb feldolgozóipari termékek gyártásában.

A különböző méretû feldolgozóipari vállalatoknál foglalkoztatottak arányának vizsgálata a vállalatok számánál és árbevételénél megállapított területi sajátosságokat követi. Az 1000 főnél többet foglalkoztató vállalatok Felső-Bajorország és KözépFrankföld térségében vannak túlnyomó többségben. Mindkét bajor régióban a feldolgozóipari foglalkoztatottak 40\%-ának a legnagyobb vállalatok adtak munkát.

Területi Statisztika, 2019, 59(2): 129-151; DOI: 10.15196/TS590201 
Azonban tartományi szinten jelentősek a különbségek a legnagyobb vállalatoknál. Az 50 és 249 fő foglalkoztatott közötti vállalatok a feldolgozóipari dolgozók 25\%-át foglalkoztatták, hasonlóan a nagyobb vállalatokhoz, ebben a kategóriában is nagy a szóródás az egyes tartományon belüli régiók között. Azokban a régiókban, amelyekben relatíve alacsonyabb a legnagyobb vállalatoknál dolgozók aránya, ott az 50 és 249 fố közötti vállalatok részesedése viszonylag magasabb. Ilyen FelsőFrankföld, Alsó-Bajorország és Svábföld (3. táblázat).

3. táblázat

\section{A feldolgozóiparban foglalkoztatottak megoszlása vállalatméret-kategóriák} szerint

Distribution of employment in the manufacturing sector, by company size

\begin{tabular}{|c|c|c|c|c|c|}
\hline NUTS 2 régió & $\begin{array}{c}50 \text { fö } \\
\text { alatt }\end{array}$ & $\begin{array}{c}50-249 \\
\text { fö }\end{array}$ & $\begin{array}{c}250-499 \\
\text { fó }\end{array}$ & $\begin{array}{c}\text { 500-999 } \\
\text { fö }\end{array}$ & $\begin{array}{c}1000 \text { fó } \\
\text { felett }\end{array}$ \\
\hline \multicolumn{6}{|c|}{2009} \\
\hline Felső-Bajorország & 7,8 & 23,8 & 13,6 & 13,6 & 41,2 \\
\hline Alsó-Bajorország & 9,3 & 31,0 & 12,7 & 14,8 & 32,1 \\
\hline Felső-Pfalz & 7,6 & 27,2 & 17,2 & 13,0 & 35,0 \\
\hline Felső-Frankföld & 9,9 & 37,0 & 17,3 & 11,4 & 24,4 \\
\hline Közép-Frankföld & 8,4 & 25,9 & 14,9 & 10,2 & 40,7 \\
\hline Alsó-Frankföld & 8,6 & 27,7 & 14,6 & 13,7 & 35,4 \\
\hline Svábföld & 9,3 & 30,5 & 15,1 & 16,3 & 28,7 \\
\hline Németországi átlag & 12,2 & 34,3 & 15,7 & 12,3 & 27,4 \\
\hline Nyugatnémet átlag & 10,3 & 31,0 & 16,0 & 12,9 & 29,7 \\
\hline Keletnémet átlag & 18,9 & 47,5 & 15,3 & 8,9 & 10,5 \\
\hline \multicolumn{6}{|c|}{2016} \\
\hline Felső-Bajorország & 7,3 & 22,4 & 12,6 & 12,7 & 44,9 \\
\hline Alsó-Bajorország & 8,4 & 30,7 & 11,9 & 14,9 & 34,1 \\
\hline Felsô-Pfalz & 7,2 & 25,2 & 18,3 & 13,6 & 35,6 \\
\hline Felső-Frankföld & 9,0 & 34,3 & 17,7 & 15,2 & 23,8 \\
\hline Közép-Frankföld & 7,6 & 24,0 & 11,4 & 12,5 & 44,5 \\
\hline Alsó-Frankföld & 8,8 & 27,5 & 16,9 & 12,1 & 34,7 \\
\hline Svábföld & 8,9 & 30,1 & 16,2 & 14,1 & 30,6 \\
\hline Németországi átlag & 11,4 & 33,3 & 16,3 & 13,2 & 27,0 \\
\hline Nyugatnémet átlag & 9,9 & 30,7 & 15,9 & 13,6 & 30,2 \\
\hline Keletnémet átlag & 17,0 & 43,1 & 18,2 & 11,0 & 10,2 \\
\hline
\end{tabular}

Forrás: A Német Szövetségi Statisztikai Hivatal adatai alapján saját szerkesztés.

Az 1970-es évektől kezdve az innovatív ágazatok ${ }^{6}$ kialakulása és támogatása a bajor gazdaságpolitika középpontjába került, majd az 1980-as években a mikro-

${ }^{6}$ Ezek közé tartozik többek között az információ- és kommunikációtechnológiai ágazat, az optikai ipar és a gyógyszeripar.

Területi Statisztika, 2019, 59(2): 129-151; DOI: 10.15196/TS590201 
elektronikai ágazat részesült elsősorban a tudatos állami fejlesztésekből. Az 1990-es években intézményesült a high-tech iparágak támogatása és fejlesztése, ezek mellett a tradicionális iparágak is középpontban maradtak (Berger 2002). Bajorországban az 1990-es évek vállalkozáspolitikai irányvonala ${ }^{7}$ egyszerre épített a high-tech innovatív és a hagyományos vállalatokra. A bajor vállalkozáspolitika egyik fontos eleme volt az ipari és innovációs klaszterek létrehozásának elősegítése. Ebben kiemelt szerepe volt a kutatási infrastruktúrának, amely 26 felsőoktatási intézményből (egyetemek, főiskolák), 12 különböző Max Planck intézetből (alapkutatási tevékenység), 13 Fraunhofer-intézetből (alkalmazott kutatás) és 3 központi kutatóintézetből állt. Leydesdorff-Fritsch (2006) elemzése arra mutatott rá, hogy Németországon belül Bajorországban dinamikus az egyetemek, a vállalatok és az állam együttmúködése. A tartományon belül ennek dinamikája eltérő, míg a metropolisz térségekkel rendelkező régiókban (Felső-Bajorország, Közép-Frankföld) kiemelkedően, addig a centrumoktól távolabb lévő területeken kevésbé dinamikus az említett három szereplő együttmúködése.

Az 1990-es években több olyan vállalkozáspolitikával kapcsolatos intézkedést is hoztak, amelyek az említett kutatóintézetek mellett hatással voltak az új vállalatok alapítására, a meglévő vállalatok tevékenységére is. Az 1994-ben indított „Future Bavaria Campaign" stratégia célja a különböző innovatív ágazatokban ${ }^{8}$ a kutatás és technológiatranszfer támogatása, az új vállalatok létrehozása, a kis- és középvállalatok nemzetközi piacokon való megjelenésének elősegitése, valamint az oktatás gyakorlati orientációjának erősítése. Hasonló célokkal indult 2000-ben a „High-Tech Campaign Bavaria", azonban a stratégián belül kiemelt szerepet kaptak az élettudományok, az energetika és a környezet, valamint az anyagtudomány és a mechatronika (HülsbeckLehmann 2007). Az említett stratégiák és céljaik megvalósítása több minisztérium együttes hatáskörébe tartozott, az érintett területtől függően. Három olyan vállalatot hoztak létre az 1990-es évek közepén, amelyeknek az volt a feladata, hogy hátteret nyújtsanak a stratégiákban említett célok teljesüléséhez. A „Bayern Innovativ GmbH” az ipari és tudományos szereplők közötti technológiatranszfert és hálózatosodást támogatta. A „Bayern Kapital GmbH” kockázati tőkét, valamint különböző pénzügyi támogatásokat nyújtott a bajor kis- és középvállalatok számára, a „Bayern International GmbH" pedig ezeknek a gazdasági szereplőknek a piacra lépését segítette. A vállalatok alapításuk óta tartományi (állami) felügyelet alatt múködtek (Hülsbeck-Lehmann 2007). A tartomány több intézményen keresztül járult hozzá a vállalkozáspolitikai stratégia teljesüléséhez. Egyrészt a meglévő, tradicionális iparágakban szereplő, elsősorban családi vállalatok megtartására, másrészt az egyetemek

\footnotetext{
${ }^{7}$ Ezt a politikát Hülsbeck és Lehmann (2007) alapján a „Between Laptop and Lederhosen”, azaz szabad fordításban a „Laptop és a bőrnadrág között” nevet viselte, amely a tradicionális ágazatok megtartását és az új, modern ágazatok megjelenését egyszerre támogatta.

${ }^{8}$ Közlekedési technológiák, anyagtudomány, környezetvédelmi technológiák, genetika, biotechnológia, orvostudomány és gyógyszeripar.
}

Területi Statisztika, 2019, 59(2): 129-151; DOI: 10.15196/TS590201 
és a vállalatok együttmúködése során létrejövő innovatív vállalatokra építve. Azonban ez a két „vonal” nem feltétlenül ugyanolyan arányban jelent meg minden régióban. Míg az elóbbi a centrumoktól távolabb lévő térségekre, addig az utóbbi inkább a nagyvárosi, a nagyobb egyetemi centrummal rendelkező térségekre jellemző.

\section{A kis- és középvállalati szektor Szászországban}

A keleti és nyugati országrészek általános összehasonlítását, valamint Bajorország kisés középvállalati trendjeinek áttekintését követően vizsgáltuk a keletnémet térség egyik jelentős, ipari múlttal rendelkező területét. A szászországi területeken (Drezda és Chemnitz térségében) a 19. században megjelent iparosodás (elsősorban a textil- és a gépipar) a meghatározó, amely magasabb vállalkozói aktivitással járt együtt (Wyrwich 2012, Fritsch et al. 2014). Jelentős gazdasági ágazat volt a fémipar, a fémfeldolgozó ipar és a gépipar (Kunath et al. 2006). Az 1945 és 1990 közötti időszak hatása jelenleg is érződik a tartomány kis- és középvállalati struktúrájában. A jelenlegi struktúra jobb megértése érdekében röviden összefoglaljuk a rendszerváltással járó változásokat. Az 1990 előtti időszakban a vállalati struktúrát az állami nagyvállalatok határozták meg, ezek viszonylag szúk termékpalettával rendelkeztek (McMillanWoodruff 2002). Azonban a többi posztszocialista országhoz viszonyítva az NDKban a piacgazdaságra történő áttérés gyorsabban és radikálisabban történt meg.

Brezinski-Fritsch (1995) ezt a következő öt - különböző, de egymással összefüg-

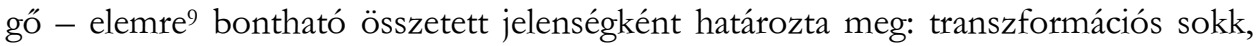
versenysokk, kínálati sokk, bérsokk, szabályozási és mentális sokk. Ezek a rendszerváltás során, valamint az azt követő években jelentek meg. A gazdasági keretrendszer megváltozása révén a foglalkoztatás visszaesett, a munkanélküliségi ráta nőtt. Ezzel együtt jelentős elvándorlás indult meg a nyugatnémet tartományok felé (Burda-Hunt 2001). A korábbi kereskedelmi kapcsolatok megszakadtak, és új beszállítói hálózatot, valamint ügyfélkört kellett kialakítani. Ennek érdekében a keletnémet (volt állami) vállalatoknak rövid idő alatt kellett javítani termékeik minőségét, a piaci versennyel járó specifikus üzleti tudást elsajátítani (Brezinski-Fritsch 1995). Az addigi termelési struktúra igen költségessé vált, egyrészt a nagyvállalatokon belüli magas fokú vertikális integráció, másrészt a bérek színvonalának emelkedése miatt (Fritsch et al. 2015). A közvetlen gazdasági okok mellett a szabályozási környezet változásának is szerepe volt. Az új jogszabályok betartását - a szocialista államban megszokottakhoz képest szigorúan ellenőrizték. A legális magántulajdon, az öngondoskodás és az egyéni felelősségvállalás megjelenése jelentős változásokat eredményezett, és ezek között pozitív és negatív folyamatok is megjelentek (Fritsch-Rusakova 2012).

${ }^{9}$ Fritsch és szerzôtársai (2015) más csoportosításban, de szintén 5 részletben vázolták fel a jelenséget.

Területi Statisztika, 2019, 59(2): 129-151; DOI: 10.15196/TS590201 
Szászország régiói és népesebb városai

NUTS 2 regions and the most populated cities of Saxony

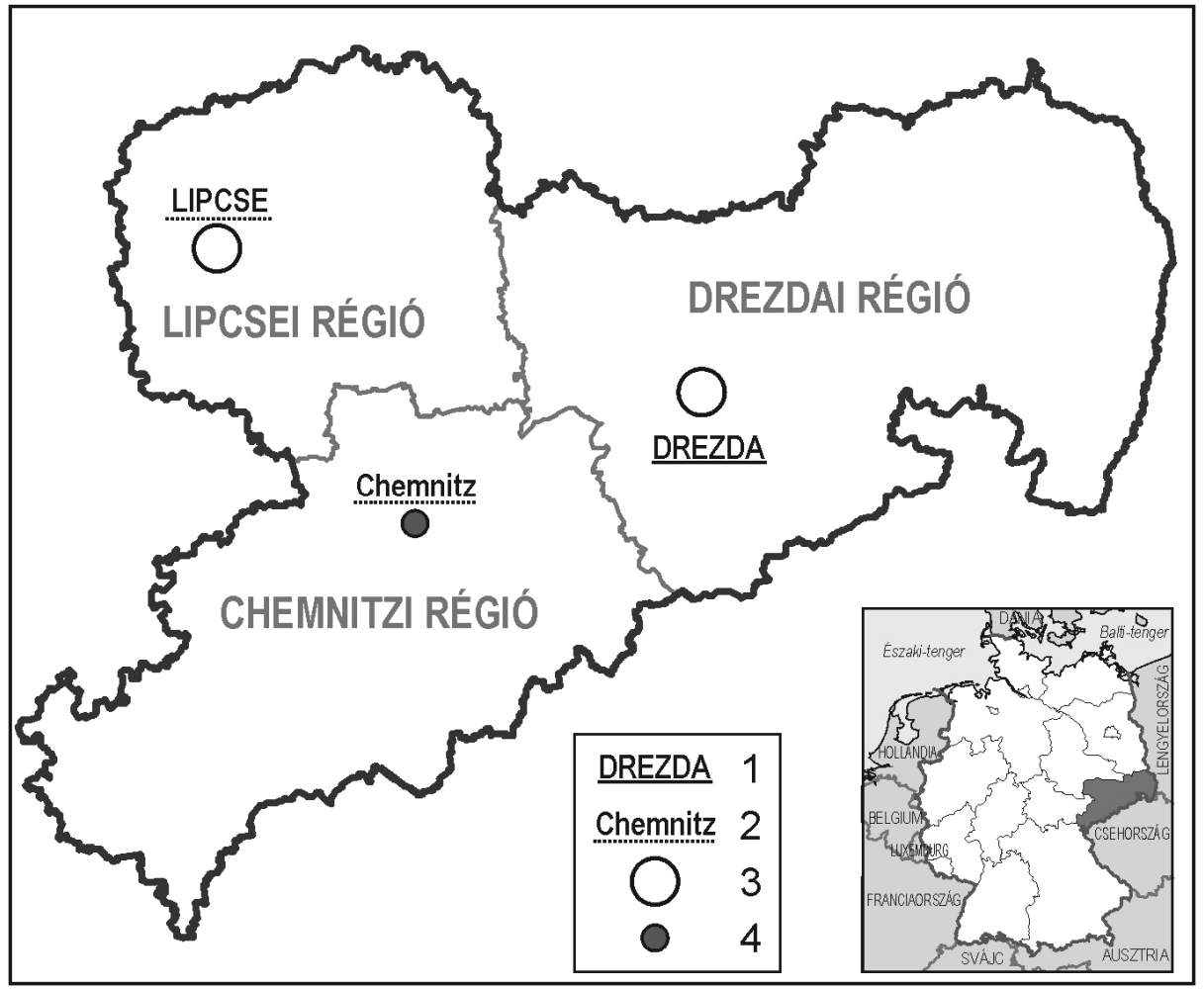

Jelmagyarázat: 1 - A tartomány székhelye; 2 - NUTS 2 térség székhelyei; 3 - 500 ezer fő feletti népességgel rendelkező város; 4 - 100 és 500 ezer fő közötti népességgel rendelkező város.

Szászországban a vállalatok számának és árbevételének megoszlása - az általános gazdasági trendeknek megfelelően - a chemnitzi és drezdai régió kiemelkedését mutatta. A háromból ebben a két térségben található a vállalatok számának 75\%-a, illetve az üzleti árbevétel nagyjából háromnegyede is itt realizálódik. A városokat tekintve Lipcse Drezdával megközelítően egyenlő értékekkel rendelkezett a vállalatok számát és azok árbevételét tekintve. Azonban a vállalatok elhelyezkedésében a lipcsei régióban jelentôsebb koncentráció mutatkozott a legnagyobb városban (Lipcse) a másik két térségnél (4. táblázat). 
4. táblázat

A vállalatok száma és árbevétele, azok megoszlása a szászországi régióban, 2016

Distribution of the number of companies and their turnover by Saxonian region

(2016)

\begin{tabular}{|c|c|c|c|c|}
\hline \multirow{2}{*}{ NUTS 2 régió } & \multicolumn{2}{|c|}{ Vállalatok } & \multicolumn{2}{|c|}{ Árbevétel } \\
\hline & száma & aránya, $\%$ & milliárd euró & aránya, $\%$ \\
\hline Chemnitz (régió) & 54599 & 36,68 & 49714498 & 38,03 \\
\hline Drezda (régió) & 57345 & 38,53 & 48520262 & 37,12 \\
\hline Lipcse (régió) & 36903 & 24,79 & 32479374 & 24,85 \\
\hline Szászország & 148847 & 100,00 & 130714134 & 100,00 \\
\hline \multirow{2}{*}{$\begin{array}{l}\text { Várostérségek aránya } \\
\text { a régiókon belül }\end{array}$} & \multicolumn{2}{|c|}{ Vállalatok } & \multicolumn{2}{|c|}{ Árbevétel } \\
\hline & száma & $\begin{array}{c}\text { aránya } \\
(100 \%=\text { régió })\end{array}$ & milliárd euró & $\begin{array}{c}\text { aránya, } \\
(100 \%=\text { régió })\end{array}$ \\
\hline $\begin{array}{l}\text { Chemnitz a chemnitzi } \\
\text { régión belül }\end{array}$ & 9842 & 18,03 & 16176974 & 32,54 \\
\hline $\begin{array}{l}\text { Drezda a drezdai régión } \\
\text { belül }\end{array}$ & 19470 & 33,95 & 20863904 & 43,00 \\
\hline $\begin{array}{l}\text { Lipcse a lipcsei régión } \\
\text { belül }\end{array}$ & 19960 & 54,09 & 20854327 & 64,21 \\
\hline
\end{tabular}

Forrás: A Szászországi Tartományi Statisztikai Hivatal adatai alapján saját szerkesztés.

A szászországi vállalatok számának méretkategóriák szerinti vizsgálata a bajorországihoz hasonló arányokat mutat: a vállalatok túlnyomó többsége mikrovállalat (94,5\%), a kisvállalatok aránya 4,5\%, amíg a középvállalatoké pedig 1\%. Összesen 260 olyan vállalat található Szászországban, amelynek árbevétele meghaladja az 50 millió eurót. A két vizsgált tartomány közötti különbséget kiemeli az árbevétel megoszlása az egyes vállalatkategóriák között. Míg Bajorországban a nagyvállalatok az árbevétel 60\%-át érték el, addig Szászországban a 33\%-át. A maradék kétharmadnyi arányból 21-21\% jut a kis- és középvállalatoknak, míg a mikrovállalatok a teljes árbevétel 24\%-át teszik ki (5. táblázat).

Területi Statisztika, 2019, 59(2): 129-151; DOI: 10.15196/TS590201 
A szászországi vállalatok száma és aránya, azok árbevételi adatai, 2016

The number and turnover of Saxonian companies (2016)

\begin{tabular}{l|cr|c|c|c|c}
\hline \multirow{2}{*}{$\begin{array}{c}\text { Vállalatméret- } \\
\text { kategória } \\
\text { (EU-definíció) }\end{array}$} & $\begin{array}{c}\text { Árbevétel- } \\
\text { kategória, } \\
\text { ezer euró }\end{array}$ & \multicolumn{2}{|c|}{$\begin{array}{c}\text { Vállalatok } \\
\text { darab }\end{array}$} & $\begin{array}{c}\text { aránya, } \\
\%\end{array}$ & $\begin{array}{c}\text { milliárd } \\
\text { euró }\end{array}$ & $\begin{array}{c}\text { aránya, } \\
\%\end{array}$ \\
\cline { 5 - 7 } & $17,5-$ & 49 & 41787 & 28,07 & 1,36 & 1,04 \\
& $50-$ & 99 & 31244 & 20,99 & 2,23 & 1,71 \\
Mikrovállalat & $100-$ & 249 & 32961 & 22,14 & 5,25 & 4,02 \\
& $250-$ & 499 & 16883 & 11,34 & 5,96 & 4,56 \\
& $500-$ & 999 & 10812 & 7,26 & 7,58 & 5,80 \\
& $1000-1999$ & 6772 & 4,55 & 9,49 & 7,26 \\
\hline \multirow{3}{*}{ Kisvállalat } & $2000-4999$ & 4934 & 3,31 & 15,19 & 11,62 \\
& $5000-9999$ & 1813 & 1,22 & 12,64 & 9,67 \\
\hline \multirow{2}{*}{ Középvállalat } & $10000-24999$ & 1025 & 0,69 & 15,78 & 12,07 \\
& $25000-49999$ & 356 & 0,24 & 12,38 & 9,47 \\
\hline Nagyvállalat & $50000-$ & 260 & 0,17 & 42,84 & 32,77 \\
\hline Összesen & & $\mathbf{1 4 8} 847$ & $\mathbf{1 0 0 , 0 0}$ & $\mathbf{1 3 0 , 7 1}$ & $\mathbf{1 0 0 , 0 0}$ \\
\hline
\end{tabular}

Forrás: A Szászországi Tartományi Statisztikai Hivatal adatai alapján saját szerkesztés.

A feldolgozóiparban az 50 és 249 főt foglalkoztató középvállalatok aránya tartományi szinten $45-47 \%$ volt. A három régiót tekintve Chemnitz és Drezda átlag feletti aránnyal rendelkezett, azonban a lipcsei régióban a 2009-es 48,8-ről 2015-re 39,4\%-ra esett vissza a középvállalatoknál dolgozó ipari foglalkoztatottak aránya. Ezt az magyarázza, hogy a vizsgált időszakban nőtt a 250-499 fős, illetve a nagyvállalatok aránya, ami ellensúlyozta a csökkenést, bár megjegyezzük, hogy az előbbi kategóriában csekély volt a növekedés. A foglalkoztatottak megoszlását tekintve megállapítható, hogy a kis- és középvállalatok határozták meg a feldolgozóipari foglalkoztatást ${ }^{10}$, ami az utóbbi évek adatai alapján csökkenő tendenciájú. A bajorországi régiók, valamint a nyugatnémet átlagértékekhez képest az 1000 fó feletti, illetve az 500 és 999 fő közötti vállalatok aránya alacsonyabb, a középvállalatoké magasabb (6. táblázat).

${ }^{10} \mathrm{Ez}$ nemcsak Szászországra, hanem a többi keletnémet tartományra is igaz. 
A feldolgozóiparban foglalkoztatottak megoszlása vállalatméret-kategóriák

6. táblázat szerint

Distribution of employment in the manufacturing sector, by company size

\begin{tabular}{|c|c|c|c|c|c|}
\hline NUTS 2 régió & $\begin{array}{l}50 \text { fó } \\
\text { alatt }\end{array}$ & $\begin{array}{c}50-249 \\
\text { fó }\end{array}$ & $\begin{array}{c}250-499 \\
\text { fó }\end{array}$ & $\begin{array}{c}\text { 500-999 } \\
\text { fó }\end{array}$ & $\begin{array}{c}1000 \text { fó } \\
\text { felett }\end{array}$ \\
\hline \multicolumn{6}{|c|}{2009} \\
\hline Chemnitz & 20,8 & 47,9 & 14,3 & na. & na. \\
\hline Drezda & 17,8 & 46,5 & 15,1 & 7,4 & 13,2 \\
\hline Lipcse & 18,7 & 48,8 & 16,4 & na. & na. \\
\hline Németországi átlag & 12,2 & 34,3 & 15,7 & 12,3 & 27,4 \\
\hline Nyugatnémet átlag & 10,3 & 31,0 & 16,0 & 12,9 & 29,7 \\
\hline Keletnémet átlag & 18,9 & 47,5 & 15,3 & 8,9 & 10,5 \\
\hline \multicolumn{6}{|c|}{2016} \\
\hline Chemnitz & 18,4 & 43,8 & 19,5 & na. & na. \\
\hline Drezda & 15,5 & 43,1 & 14,5 & 13,9 & 13,1 \\
\hline Lipcse & 16,2 & 39,6 & 17,3 & na. & na. \\
\hline Németországi átlag & 11,4 & 33,3 & 16,3 & 13,2 & 27,0 \\
\hline Nyugatnémet átlag & 9,9 & 30,7 & 15,9 & 13,6 & 30,2 \\
\hline Keletnémet átlag & 17,0 & 43,1 & 18,2 & 11,0 & 10,2 \\
\hline
\end{tabular}

Megjegyzés: „na.”- biányzó adat.

Forrás: A Német Szövetségi Statisztikai Hivatal (Statistisches Bundesamt) adatai alapján saját szerkesztés.

Összességében a szászországi vállalatszerkezet a bajor példához képest kevésbé kiegyenlített. Egyrészt olyan ágazatok vannak jelen a tartományban, amelyekben a kis- és középvállalatok a meghatározók, másrészt nagyvállalatok kevésbé vagy szinte alig vannak jelen azokból az ágazatokból, amelyek Bajorországot jellemzik. Azaz az ágazati szerkezetet is tükrözi ez a minta. Leydesdorff-Fritsch (2006) eredményei alapján Szászországban az egyetem-vállalat-állam kapcsolatrendszere a legdinamikusabb a keletnémet tartományok között, de ez viszonylag alacsony a nyugatnémet tartományokhoz képest. A tartományon belül egyértelmú a különbség a három régió között: a chemnitzi régiónál dinamikus, a drezdai régióban ehhez képest közepes, a lipcsei régióban pedig alacsony a kapcsolatrendszer dinamikája. A tartomány meghatározó felsőoktatási intézményei a drezdai és a chemnitzi régióban találhatók, továbbá a gazdaság fó súlypontja is ezen a tengelyen helyezkedik el. A lipcsei régió alacsony arányai alapvetően a térség inkább mezőgazdasági jellegével függenek össze.

Területi Statisztika, 2019, 59(2): 129-151; DOI: 10.15196/TS590201 


\section{Az Ipar 4.0 megjelenése, fejlödési lehetöségek a kis- és közép- vállalati szektorban}

A feldolgozóiparban az elmúlt években nagy jelentőséget kapott a digitalizáció, a gyártás és a termelés, illetve a logisztika. 2011-ben Hannoverben publikálták először azt a tudományos koncepciót, amelyet Ipar 4.0-nak ${ }^{11}$ neveztek el (Kagermann et al. 2013, Schwab 2016). A különböző Ipar 4.0 definícióikat áttekintve (Kagermann et al. 2013, Bauernhansl et al. 2014, Schwab 2016) megállapíthatjuk, hogy mindegyik középpontjában az informatika és a gyártás szoros integrációja, a múszaki alapokat jelentő kiber-fizikai rendszerek fejlődése, valamint a gazdasági és az üzleti modellek megváltozása áll. Egyfajta útkeresés folyik. Vannak megoldások és minták, de az Ipar 4.0 paradigma nem egyszerúsíthetô le néhány kiválasztott (informatikai, gyártástechnológiai) dimenzióra.

Az Ipar 4.0 jelenség értelmezését nem szerencsés kizárólag az iparra és az új technológiákra szúkíteni, így osztjuk Szalavetz (2015, 2016, 2017), valamint Porter és Heppelmann, (2014) véleményét, miszerint ökoszisztéma alapú megközelítés szükséges. Az Ipar 4.0 vállalatok tevékenységük során kooperálnak a gazdasági, a tudományos és a kormányzati szféra képviselőivel, és velük együtt alkotják az Ipar 4.0 ökoszisztémát. Az Ipar 4.0 víziója, miszerint a meglévő műszaki és gazdasági potenciálokra és készségekre alapozott innovációk eredményeképpen felépített okos gyár a következő átfogó ismérvek teljesülése esetén jön létre: az okos gyáron belül az emberek, a gépek és az egyéb erőforrások digitális ikermodellben képződnek le, és egymással a kiber-fizikai rendszereken keresztül kommunikálnak, ezáltal magas fokú vertikális integrációt valósítanak meg (Monostori et al. 2016, Kagermann et al. 2013). Az okos gyár mindig alkalmazkodik környezetének új igényeihez és állapotához (a megrendelésállományhoz és az anyagszükséglet rendelkezésre állásához) és önmaga optimalizálja a termelési folyamatait. Ez a teljes ellátási és értékláncban a beszállítókkal, valamint az ügyfelekkel való integráción keresztül valósul meg, amely a szereplők közötti összekapcsolódást, horizontális integrációt jelenti (Váncza et al. 2011, Bauernhansl et al. 2014). A termelési folyamatok átalakulnak (Lapp 2014), az ipari termelés integrálhatóvá válik egy intelligens környezetbe (Ostertag 2014). Porter-Heppelmann $(2014,2015)$ részletes áttekintést nyújt arra vonatkozóan, hogy az okos (smart), egymással kapcsolatban lévő folyamatok milyen hatással lesznek a termelési rendszerekre, az iparági szerkezetre, a versenytársak egymás közötti viszonyára, valamint az üzleti stratégiákra.

Az Ipar 4.0 nemcsak előnyöket, de veszélyeket is jelenthet. A termelési feladatokat a humán erőforrástól egyre inkább átvevő gépek, automata döntéshozórendszerek, szoftverek végzik. Az ilyen irányú fejlesztésekkel a vállalatok költségeiket csökkenthetik, a könnyen automatizálható emberi tevékenységek gépekkel, robotokkal válthatók ki. A felszabaduló emberi erőforrást intuitív és kreatív feladatokra

\footnotetext{
${ }^{11}$ Eredeti német nevén Industrie 4.0, angolul Industry 4.0.
}

Területi Statisztika, 2019, 59(2): 129-151; DOI: 10.15196/TS590201 
használhatják. Ezen kettősség magában hordozza, hogy az elóbbi hatására a kevésbé képzett vagy képzetlen munkaerő felszabadul, munkaerô-túlkínálat várható, utóbbi esetében a megnövekedett igények kielégítése munkaerőhiányt eredményezhet.

A német szövetségi kormány 2006-ban meghirdette, majd 2014-ben, illetve 2016-ban az általa irányított Plattform Industrie 4.0 közremúködésével aktualizálta High-Tech Stratégiáját. Ennek célja, Németország világpiaci vezető szerepének erősítése, versenyképességének fokozása. A stratégia prioritásnak tekinti a kis- és középvállalatok pozíciójának javítását és fejlesztését (Die Neue High-Tech Strategie, 2014). Célja, hogy Németország innovációs dinamikájának gyorsítása érdekében a kutatás és fejlesztés költségeit viselő nagyvállalatok mellett a kis- és középvállalatok is bekapcsolódjanak az értékteremtési folyamatokba. E célból a német kormány anyagi, tanácsadói segítséget nyújtó programokat hirdetett meg, illetve ezeket támogató hálózatokat hozott létre. Az Ipar 4.0 növeli a kis- és középvállalatok versenyképességét, az automatizáció által költségcsökkenést és rugalmas gyártást, a keletkező adatok feldolgozása alapján optimalizált belső múködést és az ügyféligényekre való gyors reagálást tesz lehetővé. A megosztott használatú, felhőalapú technológiák gyártási és termelési folyamatba illesztése, a szabványosítás pedig olyan eszközök elérését biztosítja számunkra, melyeket nem lennének képesek önállóan sem finanszírozni, sem üzemeltetni (Schröder et al. 2015).

Az Ipar 4.0 projektek területi eloszlásának vizsgálata (3. ábra) azt mutatja, hogy a projektek nagyobb része a nyugati tartományokban, de ezen belül is alapvetően három tartományban összpontosul (ezek között van Bajorország is). Az egyes tartományokon belül is elónyös helyzetben vannak azok a régiók, amelyek felsőoktatási és tudományos központot (vagy központokat) is magukban foglalnak. Ezért Bajorországból két területet lehet kiemelni, Felső-Bajorországot (19 projekt) és KözépFrankföldet (8 projekt), a keleti tartományok közül pedig Berlint és Brandenburgot. Utóbbi esetében a magas projektszám feltételezhetően a berlini agglomerációban található kutatás-fejlesztést végző felsőoktatási intézményeknek, valamint a Berlin környékén székhellyel rendelkező vállalatoknak köszönhető. A berlini térséget kivéve azonban nincs másik térség, amely kiemelkedő lenne az Ipar 4.0 projektek tekintetében, mindössze néhány projektet lehet megfigyelni keletnémet tartományonként. Talán egy kivétel van, a chemnitzi régió (4 projekt), ahol az átlagosnál valamivel több a projektek száma.

Területi Statisztika, 2019, 59(2): 129-151; DOI: 10.15196/TS590201 
Az Ipar 4.0 projektek száma Németországban régiónként, 2017

Number of Industrie 4.0 projects in the NUTS 2 regions

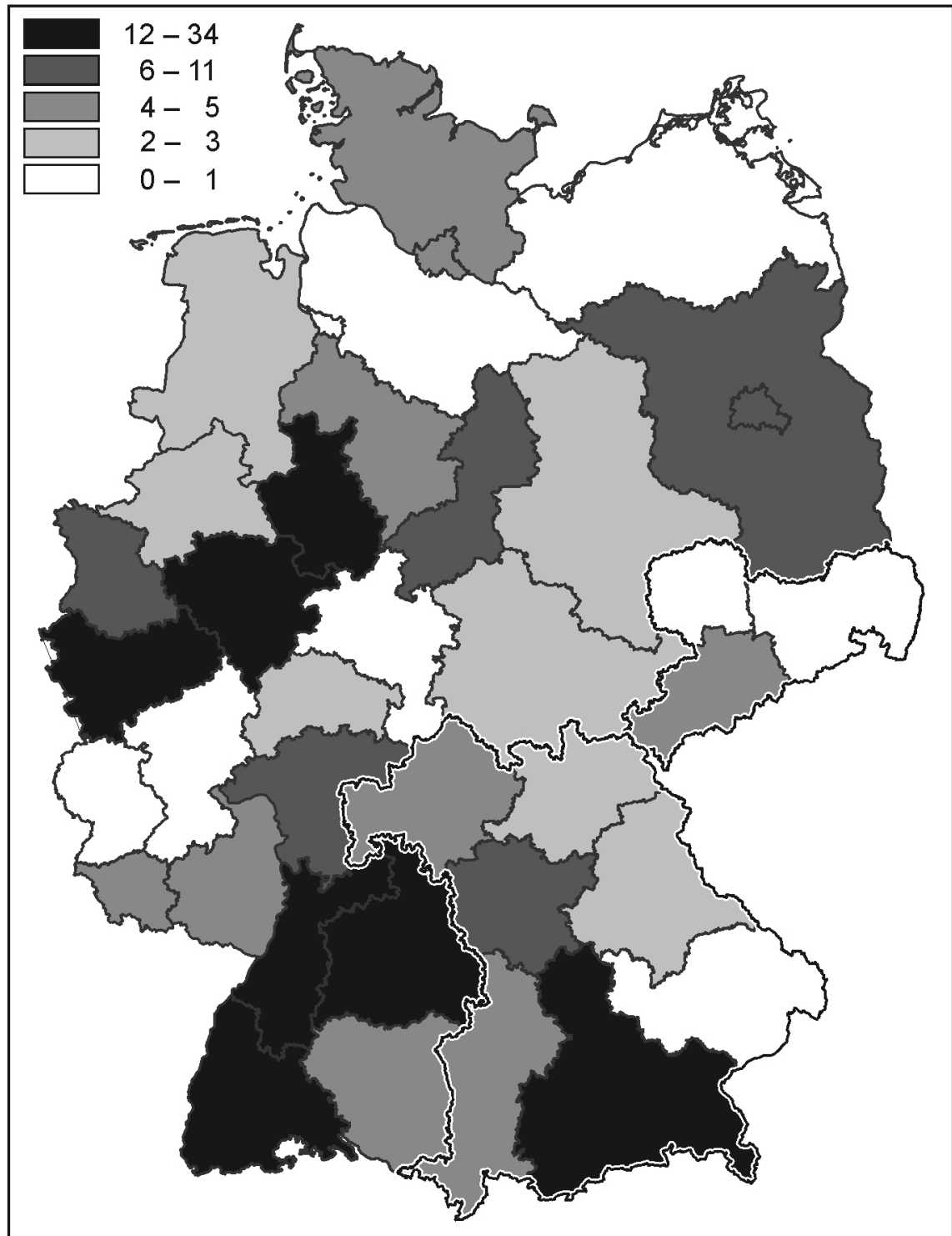

Forrás: A https://www.plattform-i40.de/I40/Navigation/DE/In-der-Praxis/Karte/karte.html alapján (letöltés: 2017. febr. 11.) saját szerkesztés. 
A projektek eloszlásáról megállapítható, hogy főleg azokban a régiókba összpontosulnak, amelyek fejlett kutatás-fejlesztési és tudományos infrastruktúrával rendelkeznek, illetve amelyekben innovatívabbak a vállalatok. Így az Ipar 4.0 projektek pozitív hatásai a fejlettebb régiókban jelentkezhetnek, és ez tovább növelheti a különbséget a két országrész között.

\section{Következtetések}

A tanulmány célja az volt, hogy felvázolja a kis- és középvállalati szektor regionális különbségeit Németországban. Azért fókuszáltunk erre az országra, mert történelmi okok miatt egy sajátos, párhuzamos fejlődést figyelhetünk meg az ország két részének feldolgozóipari kis- és középvállalati szektorában. A kelet-nyugati összehasonlítás eredményeiben megmutatkoztak a két gazdasági rendszer közötti különbségek, valamint a keletnémet rendszerváltást követô problémák is. A nyugatnémet tartományokban a helyi és regionális gazdaság alapvető elemét képezik a Mittelstand vállalatok, továbbá közülük többen jelentős nagyvállalattá nőtték ki magukat.

A bajorországi vállalati struktúra azt mutatta, hogy az üzleti forgalom (árbevétel) 60\%-át a nagyvállalatok adják, és amennyiben csak a feldolgozóipart vesszük figyelembe, úgy szintén a legnagyobb vállalatok vannak túlnyomó többségben. Bár az egyes régiók értékei egymástól eltérőek, azonban minden bajorországi térségre jellemző ez a trend. A bajor vállalkozáspolitika a meglévő vállalkozói tradíciókat kombinálja az új, high-tech ágazatokra és kutatás-fejlesztésre épülő vállalkozáspolitikai kezdeményezésekkel, hogy a kutatás és technológiatranszfer révén támogassa mind a már meglévő, mind az újonnan piacra lépő vállalatok innovációs potenciáljának növelését. Ezzel szemben a keleti országrészben a Mittelstand vállalatok csak 1990 után jelenhettek meg, ugyanis addig az állami nagyvállalatok jellemezték a gazdaságot. Az összeomló, majd a korábbi állami vállalatok használható és még helyben maradó erőforrásain (például telephely és humán tőke) fokozatosan létrejöttek a feldolgozóipari kis- és középvállalatok. Nagy jelentősége volt annak, hogy a rendszerváltást követően mennyire gyorsan tudott újraindulni a helyi és a regionális gazdaság. Szászország a keletnémet térség egyik legfejlettebb iparával rendelkező tartománya, ahol támogatták a vállalkozói kultúra kialakulását, alapot biztosítva a rendszerváltást követô társadalmi-gazdasági átalakuláshoz. Vizsgálatunk azonban azt bizonyította, hogy a keletnémet nagyvállalatok még nincsenek annyira meghatározó szerepben, mint Bajorországban. Ezt támasztják alá az árbevétellel kapcsolatos eredmények, valamint a feldolgozóiparban foglalkoztatottak vállalatméret-kategóriák szerinti megoszlása is. Ahhoz azonban, hogy a középvállalatok továbbfejlődésére (adott esetben nagyvállalattá válására) lehetőség nyíljon, megfelelő kutatás-fejlesztési infrastruktúra és együttmúködés szükséges. Ezek egyelőre a tartomány regionális központjaiban és azok agglomerációs térségeiben jellemzők.

Területi Statisztika, 2019, 59(2): 129-151; DOI: 10.15196/TS590201 
A kis- és középvállalati szektor jövőjét nagymértékben befolyásolja a digitalizáció, valamint az új termelési eljárások. Ezek a feldolgozóipari termelési innovációk az Ipar 4.0 projektek keretében jelenleg is megvalósítás alatt vannak. Azonban a projektek területi megoszlásából arra következtethetünk, hogy az Ipar 4.0 keretében megvalósuló innovációk olyan régiókban jelenhetnek meg, amelyek megalapozott kutatás-fejlesztési és tudományos infrastruktúrával rendelkeznek.

\section{Köszönetnyilvánítás}

A szerzők köszönetüket fejezik ki Lux Gábornak a tanulmány korábbi verzióihoz tett észrevételeiért, Fonyódi Valériának és Szabó Tamásnak az ábrák elkészítéséért, valamint a lektoroknak a tanulmánnyal kapcsolatos véleményeikért.

A tanulmány az NKFIH K115577. számú projekt keretében, a Nemzeti Kutatási Fejlesztési és Innovációs Alap támogatásával valósult meg.

\section{IRODALOM}

Arnold, M.-Eickelpasch, A.-Fritsch, M.-Mattes, A.-Schiersch, A. (2015): Die ostdeutsche Wirtschaft ist zu kleinteilig strukturiert DIW Wochenbericht 35: 764-772.

Bauernhansl, T.-Hompel, M. T.-Vogel-Heuser, B. (2014): Industrie 4.0 in Produktion, Automatisierung und Logistik: Anwendung, Technologien, Migration Springer, Wiesbaden.

BERGER, C. (2002): Technologie- und Innovationspolitite in Bayern WSI-Diskussionspapier, 105., Wirtschafts- und Sozialwissenschaftliches Institut in der Hans-Böckler-Stiftung, Düsseldorf.

BreZINSKI, H.-FriTSCH, M. (1995): Transformation: The shocking German way Moct-Most Economic Policy in Transitional Economics 5 (1): 1-25. https://doi.org/10.1007/BF00996593

Buenstorf, G.-GueNTHER, C. (2011): No place like home? Relocation, capabilities, and firm survival in the German machine tool industry after World War II. Industrial and Corporate Change 20 (1): 1-28. https://doi.org/10.1093/icc/dtq055

Burda, M.-HunT, J. (2001): From Reunification to Economic Integration: Productivity and the Labor Market in Eastern Germany Brookings Papers on Economic Activity 2: $1-71$.

ERKER, P. (1991): Keine Sehnsucht nach der Ruhr. Grundzüge der Industrialisierung in Bayern 1900-1970. Geschicbte und Gesellschaft 17 (4): 480-511.

Falck, O.-Guenther, C.-Heblich, S.-KerRY, W. (2013): From Russia with love: the impact of relocated firms on incumbent survival Journal of Economic Geography 13 (3): 419-449. https://doi.org/10.1093/jeg/lbs035

FRITSCH, M. (2004): Entrepreneurship, entry and performance of new business compared in two growth regimes: East and West Germany Journal of Evolutionary Economics 14 (5): 525-542. https://doi.org/10.1007/s00191-004-0230-z

Fritsch, M.-BublitZ, E.-SORgner, A.-Wyrwich, M. (2014): How much of a socialist legacy? The re-emergence of entrepreneurship in the East German

Területi Statisztika, 2019, 59(2): 129-151; DOI: 10.15196/TS590201 
transformation to a market economy Small Business Economics 43 (2): 427-446. https://doi.org/10.1007/s11187-014-9544-x

FrITSCH, M.-FrANKE, G. (2004): Innovation, regional knowledge spillovers and R\&D cooperation Research Policy 33 (2): 245-255. https://doi.org/10.1016/S00487333(03)00123-9

FritsCH, M.-RuSAKOVA, A. (2012): Self-employment after socialism: Intergenerational links, entrepreneurial values, and buman capital SOEPpapers on Multidisciplinary Panel Data Research, No. 456. Deutsches Institut für Wirtschaftsforschung (DIW), Berlin. http://hdl.handle.net/10419/60191 (letöltve: 2018.01.10.)

FritsCH, M.-SORgNER, A.-WYRWICH, M. (2015): Die Entwicklung der Wirtschaft in Ostdeutschland nach der Wiedervereinigung Gesellschaft. Wirtschaft. Politik (GWP) 2: 225-238.

FritsCH, M.-WyrWICH, M. (2014): The Long Persistence of Regional Levels of Entrepreneurship: Germany, 1925-2005 Regional Studies 48 (6): 955-973. https://doi.org/10.1080/00343404.2013.816414

Heimpold, G. (2005): Unternehmensnetzwerke in Ostdeutschland: Konzentration auf Verdichtungsräume Wirtschaft im Wandel 4: 118-124.

Holz, M. (2013): Strategies and policies to support the competitiveness of German Mittelstand companies In: ColtorTi, F.-Resciniti, R.-Tunisini, A.-VARALDO, R. (eds.): Mid-sized Manufacturing Companies: The New Driver of Italian Competitiveness pp. 147-168., Springer-Verlag Italia, Milano.

Horváth, Gy. (2013): A német Mezzogiorno? A keletnémet regionális fejlődés az újraegyesítés után Területi Statisztika 53 (5): 492-514.

HÜlsBeCK, M.-Lehmann, E. (2007): Entrepreneurship Policy in Bavaria: Between Laptop and Lederhosen In: Audretsch, D. B.-Grilo, I.-Thurik, A. R. (eds.): Handbook of Research on Entrepreneurship Policy pp. 200-212., Edward Elgar Publishing, Cheltenham.

INOTAI, A. (1986): Az NSZK a változó világgazdaságban Közgazdasági és Jogi Könyvkiadó, Budapest.

Kagermann, H.-WAhlster, W.-Helbring, J. (2013): Securing the Future of German Manufacturing Industry: Recommendations for Implementing The Strategic Initiative Industrie 4.0. Final report of the Industrie 4.0 Working Group Forschungsunion im Stifterverband für dir Deutsche Wirtschaft e.V., Berlin

KŐRÖSI, I. (2014): Kettős kötődés: Németország gazdasági helyzete, szerepe az európai integrációban és Közép-Európában, az 1990-2013-as időszakban Külügyi Sz̧mle 1: 35-68.

KovÁCs, Sz. (2014): Területi különbségek Bajorországban Köztes Európa: Társadalomtudományi Folyóirat: A Vikek Közleményei 6 (2-3): 35-42.

LApp Group AG (2014): Die Zukunftsfabrik. Kabelwelt: Industrie 4.0 Revolution in der Fabrikballe 2: 6-10.

LEYDESDORFF, L.-FRITSCH, M. (2006): Measuring the knowledge base of regional innovation systems in Germany in terms of a Triple Helix dynamics Research Policy 35 (10): 1538-1553. https://doi.org/10.1016/j.respol.2006.09.027

Területi Statisztika, 2019, 59(2): 129-151; DOI: 10.15196/TS590201 
McMillan, J.-Woodruff, C. (2002): The Central Role of Entrepreneurs in Transition Economies The Journal of Economic Perspectives 16 (3): 153-170. https://doi.org/10.1257/089533002760278767

Monostori, L.-KÁdÁr, B.-BAuernhansl, T.-KOndOH, T.-KumarA, S.-ReinHART, G.-SAUER, O.-SCHUH, G.-SiHN, W.-UEDA, K. (2016): Cyber-physical systems in manufacturing CIRP Annals - Manufacturing Technology 65 (2): 621-641. https://doi.org/10.1016/j.cirp.2016.06.005

Ostertag, A. (2014): Industry 4.0: Flexible production with Plug \& Produce Festo AG \& Co. KG, Esslingen am Neckar

Porter, M. E.-Heppelmann, J. E. (2014): How smart, connected products are transforming competition Harvard Business Review 92 (11): 64-88.

Porter, M. E.-Heppelmann, J. E. (2015): How smart, connected products are transforming companies Harvard Business Review 93 (10): 96-114.

RagnitZ, J.-Heimpold, G.-Hölscher, J.-LAND, R.-Schroeder, K. (2015): 25 Jahre Deutsche Einheit: eine Erfolgsgeschichte? Wirtschaftsdienst 95 (6): 375-394. https://doi.org/10.1007/s10273-015-1837-4

RECHNITZER, J.-SMAHÓ, M. (2011): Területi politika Akadémiai Kiadó, Budapest.

SCHRÖDER, C.-SCHLEPPHORST, S.-KAY, R. (2015): Bedeutung der Digitalisierung im Mittelstand IfM-Materialen, 244. Institut für Mittelstandsforschung, Bonn.

SCHWAB, K. (2016): The Fourth Industrial Revolution World Economic Forum, Geneva.

SZALAVETZ, A. (2016): Az ipar 4.0 technológiák gazdasági hatásai: egy induló kutatás kérdései Külgazdaság 60 (7-8): 27-50.

SZALAVETZ, A. (2017): Ipar 4.0 technológiák és környezeti fenntarthatóság: magyar feldolgozóipari tapasztalatok Külgazdaság 61 (7-8): 28-45.

VÁnCZA, J.-Monostori, L.-LutTers, E.-Kumara, S. R.-Tseng, M.-VAlckenaers, P.VAN BRUSSEL, H. (2011): Cooperative, responsive manufacturing enterprises CIRP Annals - Manufacturing Technology 60 (2): 797-820. https://doi.org/10.1016/j.cirp.2011.05.009

VONYÓ, T. (2006): Modell Deutschland ProPannónia Kiadói Alapítvány, Pécs.

WeLter, F. (2007): Entrepreneurship in West and East Germany International Journal of Entrepreneurship and Small Business 4 (2): 97-109. https://doi.org/10.1504/IJESB.2007.011838

Welter, F.-Bijedić, T.-Hoffmann, M. (2015): Triebwerk des Erfolgs - Der deutsche Mittelstand im Fokus GE Capital Deutschland - Institut für Mittelstandsforschung, Bonn.

WyrWICH, M. (2012): Regional Entrepreneurial Heritage in a Socialist and a Postsocialist Economy Economic Geography 88 (4): 423-445. https://doi.org/10.1111/j.19448287.2012.01166.x

WyrwiCH, M. (2013): The Role of Regional Conditions for Newly Emerging KIBS Industries in the Face of Radical Institutional Change European Planning Studies 21 (11): 1760-1778. https://doi.org/10.1080/09654313.2012.753694 


\section{INTERNETES HIVATKOZÁSOK}

Kunath, J.-Kosensky, W.-BuZe, A.-Winkler, I. (2006): Die Firmenlandschaft kleiner und mittlerer Unternehmen in Sachsen Schriften zur Organisationswissenschaft: Forschungsberichte und -aufsätære, 9. http://nbn-resolving.de/urn:nbn:de:101:120080715106 (letöltve: 2018.01.07.)

SZALAVETZ, A. (2015) Szakosodás és feljebb lépés a multinacionális vállalatok globális értékláncain belül MTA doktora disszertáció, Budapest. http://real-d.mtak.hu/861/7/dc_1027_15_doktori_mu.pdf (letöltve: 2017.12.12.)

DiE NEUE HighteCH-STRATEGIE INNOVATIONEN FÜR DEUTSCHLAND https://www.bmbf.de/pub_hts/HTS_Broschure_Web.pdf (letöltve: 2018.02.20.)

Területi Statisztika, 2019, 59(2): 129-151; DOI: 10.15196/TS590201 